\title{
DESIGN SYNTHESIS OF NOVEL ACRIDINE TAGGED PYRAZOLE DERIVATIVES AS AURORA KINASE INHIBITORS
}

\author{
HARATHI PERKA ${ }^{1}$, SATYAVATI ${ }^{2}$, DEEPAK REDDY GADE ${ }^{3}$, VIVEKANANDA BOYA ${ }^{1}$, RAJENDRA PRASAD VVS ${ }^{3 *}$
}

${ }^{1}$ Department of Pharmaceutical Chemistry, Teegala Krishna Reddy College of Pharmacy, Hyderabad, Telangana, India. ${ }^{2}$ Department of Pharmacology, Brilliant Grammar School Educational Society's Group of Institutions (Faculty of Engineering and Faculty of Pharmacy), Hyderabad, Telangana, India. ${ }^{3}$ Department of Pharmaceutical Chemistry, Vishnu Institute of Pharmaceutical and Educational Research, Narsapur, Telangana, India. Email: rajendraprasad.vvs@viper.ac.in

Received: 31 January 2020, Revised and Accepted: 11 March 2020

\section{ABSTRACT}

Objective: A series of novel synthesis of 5-Substituted-3-phenyl-4,5-dihydro-pyrazole-1-carbothioic acid [4-(9, 10-dihydro-acridin-9-yl)-phenyl]amide (IV) were synthesized using standard procedures and evaluated for cytotoxic studies.

Methods: 9-(4-Chloro-phenyl)-9 and 10-dihydro-acridine (I) were formed by cyclization of diphenylamine with substituted acids in the prescience of zinc chloride and synthesis of 5-substituted-3-phenyl-4, 5-dihydro-pyrazole-1-carbothioic acid amide (3) by the cyclization of different chalcones (II) and final compounds were synthesized by fusion of 5-substituted-3-phenyl-4, 5-dihydro-pyrazole-1-carbothioic acid amide (III) with 9-(4-Chlorophenyl)-9, 10-dihydro-acridine (I) by microwave irradiation method. Characterization of synthesized compounds by infrared, ${ }^{1} \mathrm{H}$ nuclear magnetic resonance (NMR), ${ }^{13} \mathrm{C}$ NMR, and mass spectroscopic methods. Obtained compounds were evaluated for their cytotoxicity against human breast cancer cell lines (MCF/wt) by sulforhodamine-B assay. Docking studies with Aurora kinase protein were performed to elucidate the possible mechanistic insights of these novel acridine tagged pyrazole derivatives.

Results: Moderate to good in vitro cytotoxic potentials of the newly synthesized molecules was reported against selected human breast cancer cell lines. Among the tested molecules, compound C6 showed good cytotoxic activity against MCF/wt $(08.2 \pm 0.4 \mu \mathrm{M})$. The dock scores of the tested compounds were ranged between -8.926 and -5.139 . Compound 66 which has been reported as the most effective cytotoxic agent among the series also reported the highest dock score of -8.926 and showed hydrogen bond interaction with GLU-211, LYS-162, and LYS-143. Ligand binding energy with protein suggested compound C6 has shown the highest binding energy of $-86.32133 \mathrm{kcal} / \mathrm{mol}$.

Conclusion: The in vitro studies of the newly synthesized acridine tagged pyrazole derivatives reported considerable cytotoxic potentials against human breast cancer cell lines and structure-activity relationship studies to suggest that acridine tagged pyrazole derivatives with hydroxy group present on phenyl ring at fifth position of pyrazole ring could probably increase the cytotoxic potentials. With the reported bioactivities of these derivatives, further studies on the derivatization could elucidate the broader cytotoxic potentials

Keywords: Microwave irradiation, Acridine, Pyrazoles, Chalcones, Aurora kinase.

(c) 2020 The Authors. Published by Innovare Academic Sciences Pvt Ltd. This is an open access article under the CC BY license (http://creativecommons. org/licenses/by/4. 0/) DOI: http://dx.doi.org/10.22159/ajpcr.2020.v13i5.36997

\section{INTRODUCTION}

Across the world, cancer is being considered as a major cause for elevated mortality rate in humans. Among women, breast cancer is the most prevalent cancers with an estimate of 255,180 new cases, respectively [1]. Elevated levels of Aurora kinases detected in wide variety of human cancers strongly indicate that high expression of these kinases plays an important role in the development of anticancer molecules as aurora kinase inhibitors [2]

Acridine $\left(\mathrm{C}_{13} \mathrm{H}_{9} \mathrm{~N}\right)$ is a nitrogen heterocycle, which is structurally related to anthracene with one of the central $\mathrm{CH}$ groups replaced by nitrogen. The acridines were first developed as dyes and during the early $20^{\text {th }}$ century their pharmacological properties were evaluated. At this time, proflavine was used as a topical antibacterial and antifungal agent [3]. In the 1940's and to the present day, the acridines (e.g., quinacrine, pyronaridine, and acranil) have been used as antimalarial drugs [4]. The first acridinebased therapeutic agents specifically designed for cancer treatment were developed during the 1970's. These efforts led to the development of $m$-amsacrine, a 9-anilinoacridine introduced into clinical use in 1976 [5]. Accordingly, this acridine has been clinically utilized as a single agent or in combination with other anti-neoplastic drugs in the treatment of acute nonlymphocytic, lymphocytic [6,7] and acute myeloid [8], leukemias [9]. However, $m$-Amsacrine has not generally been effective in the treatment of solid tumors [10]. Acridine has an irritating odor. It crystallizes in colorless to light yellow needles with melting point of $110^{\circ} \mathrm{C}$ and boiling point of $346^{\circ} \mathrm{C}$. It is characterized by its irritating action on skin and by the blue fluorescence showed by solutions of its salts.

Pyrazoles are five member ring heterocyclic compounds, have some structural features with two nitrogen atoms in adjacent position, and are also called as azoles [11].

$\beta$-[1-pyrazolyl] alanine was isolated from the seeds of water melons (Citrullus lanatus). The best described property of almost every group of pyrazoles is in the treatment of inflammation and inflammation associated disorders, such as arthritis [12]. Pyrazole derivatives are the subject of many research studies due to their widespread potential biological activities such as antimicrobial [13], antihistaminic [14], antidepressant [15], 5- $\alpha$-reductase inhibitor [16], antiproliferative [17], and herbicides [18]. During the years, pyrazoles are proved to be potent Aurora kinase inhibitors $\left(\mathrm{IC}_{50}=0.16 \pm 0.03 \mu \mathrm{M}\right)$ [19].

\section{METHODS}

Chemistry

All the chemicals were obtained from Sigma-Aldrich chemical company (USA), Lancaster (USA) and S.D. Fine chem. Limited (Mumbai). All the 
glassware is of borosilicate grade. Melting points were determined in open capillaries and are uncorrected. The purity of the compounds was ascertained by thin-layer chromatography (TLC) on silica gel-G plate.

Fourier transform infrared (IR) spectra were taken in $\mathrm{KBr}$ on a Thermo Nicolet Nexus 670 spectrophotometer. ${ }^{1} \mathrm{H}$ nuclear magnetic resonance (NMR) spectra were recorded on AVANCE $300 \mathrm{MHz}$ spectrophotometer in $\mathrm{CDCl}_{3}$ with tetramethylsilane (TMS) as internal standard. ${ }^{13} \mathrm{C}$ NMR spectra were recorded on BRUKER AVANCE $300 \mathrm{MHz}$ spectrometer in $\mathrm{CDCl}_{3}$ with TMS as an internal standard. The chemical shift values are in $\delta p p m$. Mass spectra were recorded on Polaris Q apparatus (Thermo Electron) and the fragmentations were obtained by electronic impact (EI). The data are given as mass to charge ratio $(\mathrm{m} / \mathrm{z})$ and nominal masses were used for the calculation of molecular weights of the prepared products.

\section{Synthetic procedure}

Step 1: General procedure for synthesis of 9-(4-chlorophenyl)-9, 10-dihydroacridine (1)

A mixture of diphenylamine $(0.01 \mathrm{~mol})$ and 4-Chloro benzoic acid $(0.01 \mathrm{~mol})$ was taken in a conical flask. To this zinc chloride $(0.01 \mathrm{~mol})$ was added as solvent. Then, the reaction mixture was irradiated under microwave irradiation at $450 \mathrm{~W}$ for $11 \mathrm{~min}$. The precipitate obtained after cooling is filtered and recrystallized with methanol.

\section{Step 2: General procedure for synthesis of chalcones (II)}

Equimolar quantity of different aldehydes $(0.01 \mathrm{~mol})$ and acetophenone $(0.01 \mathrm{~mol})(1.2 \mathrm{~mL})$ was placed in $30 \mathrm{~mL}$ of ethanol. The mixture was allowed to stir for $15 \mathrm{~min}$. A $10 \mathrm{~mL} 40 \%$ aqueous potassium hydroxide solution was slowly added dropwise to the reaction flask through a dropping funnel. The reaction solution was allowed to stir at room temperature for $1.5 \mathrm{~h}$. The solid separates and was collected by suction filtration.

Step 3: General procedure for synthesis of 5-substituted-3-phenyl-4, 5-dihydro-pyrazole-1-carbothioic acid amide (III)

A mixture of chalcones (II) $(0.01 \mathrm{~mol})$, thiosemicarbazide $(0.01 \mathrm{~mol}$, $0.91 \mathrm{~g})$, and $\mathrm{KOH}(0.0025 \mathrm{~mol}, 1.4 \mathrm{~g})$ was refluxed in ethanol $(30 \mathrm{~mL})$ for $6 \mathrm{~h}$. The solution was poured into ice-water. The precipitate was filtered and recrystallized from methanol.

Step 4: General procedure for the synthesis of 5-substituted-3-phenyl-4, 5-dihydro-pyrazole-1-carbothioic acid [4-(9, 10-dihydro-acridin-9-yl)phenyl]-amide (IV)

In a $250 \mathrm{ml}$ flask, a mixture of $(0.03 \mathrm{~mol})$ of 5 -substituted-3-phenyl-4, 5-dihydro-pyrazole-1-carbothioic acid amide (III), (0.0256 mol) of 9-(4-Chloro-phenyl)-9, 10-dihydro-acridine (1), and $80 \mathrm{ml}$ of 2-butanol was taken and subjected to microwave irradiation for $3 \mathrm{~min}$ at $65 \%$ intensity $(455 \mathrm{~W})$. Completion of the reaction was monitored by TLC using n-hexane and ethyl acetate in 6:4 ratio. After completion, the reaction mixture was allowed to cool at room temperature then it was poured into $150 \mathrm{ml}$ of ice water. A precipitate formed was filtered by suction, washed with water and dried recrystallized from ethanol.

The spectral data for all the newly synthesized compounds were completely in agreement with the proposed structures.

N-(4-(9,10-dihydroacridin-9-yl)phenyl)-5-phenoxy-3-phenyl-4,5dihydro-1H-pyrazole-1-carbothioamide (C1)

Light yellow color solid, yield-72\%, m.p. $310-312^{\circ} \mathrm{C}$, IR (KBr): $1597 \mathrm{~cm}^{-1}$ $(-\mathrm{NH}-), 1487 \mathrm{~cm}^{-1}(\mathrm{C}=\mathrm{S})$, and $1680 \mathrm{~cm}^{-1}\left(-\mathrm{OCH}_{3}\right),{ }^{1} \mathrm{H} \mathrm{NMR}\left(\mathrm{CDCl}_{3}\right): \delta \mathrm{ppm}$ $2.5\left(\mathrm{~s}, 2 \mathrm{H}-\mathrm{CH}_{2}\right.$ protons), $\delta$ ppm 4.0 (s, $1 \mathrm{H}-\mathrm{NH}$ proton), $\delta \mathrm{ppm} 4.7(\mathrm{~s}, \mathrm{CH})$, $\delta$ ppm 4.7 (s, 3H-OCH ${ }_{3}$ protons). and $\delta$ ppm 6.9-8.0 (m, 21H- Aromatic protons), M.W-552.69 g/mol, EI-MS: m/z 554(M+1).

3, 5-Diphenyl-4, 5-dihydro-pyrazole-1-carbothioic acid [4-(9, 10-dihydroacridin-9-yl)-phenyl]-amide (C2)

White color solid, yield-63\%, m.p. $323-325^{\circ} \mathrm{C}$, IR (KBr): $1625 \mathrm{~cm}^{-1}$ (-NH-) and $1494 \mathrm{~cm}^{-1}(\mathrm{C}=\mathrm{S}),{ }^{1} \mathrm{H}$ NMR $\left(\mathrm{CDCl}_{3}\right): \delta \mathrm{ppm}: 2.1\left(\mathrm{~s}, 2 \mathrm{H}^{-\mathrm{CH}_{2}}\right.$ protons), 4.1 (s, $1 \mathrm{H}-\mathrm{NH}$ protons), 3.8 (s,1H-N-CH protons) 5.7 (s,1H-CH protons) and 7.2-8.0 (m, $22 \mathrm{H}-\mathrm{Ar}-\mathrm{H}), \mathrm{M} . \mathrm{W}-536.69 \mathrm{~g} / \mathrm{mol}$, EI-MS: $\mathrm{m} /$ z536(M). ${ }^{13} \mathrm{C}$ NMR $\left(100 \mathrm{MHz}, \mathrm{CDCl}_{3}\right) \delta \mathrm{ppm}$ 117.92-143.24 represents 30 aromatic carbons, $\delta$ ppm 156.09 represents $\mathrm{C}=\mathrm{N}$ carbon, $\delta \mathrm{ppm}$ 43.23 represents Pyrazole $\mathrm{CH}_{2}$ carbon, $\delta$ ppm 63.08 represents pyrazole CH carbon, $\delta$ ppm 176.91 represents C=S carbon. M.W-536.69 g/mol, EI-MS: m/z 536(M).

3-Phenyl-5-styryl-4, 5-dihydro-pyrazole-1-carbothioic acid [4-(9, 10-dihydro-acridin-9-yl)-phenyl]-amide (C3)

Light yellow color solid, yield-55\% yield, m.p. $310-312^{\circ} \mathrm{C}$, IR $(\mathrm{KBr})$ : $1502 \mathrm{~cm}^{-1}(-\mathrm{NH}-), 1400 \mathrm{~cm}^{-1}(\mathrm{C}=\mathrm{S})$, and $1311 \mathrm{~cm}^{-1}\left(-\mathrm{CH}=\mathrm{CH}_{2}\right),{ }^{1} \mathrm{H}$ NMR ( $\mathrm{CDCl}_{3}$ ): $\delta$ ppm: 2.0 (s, $2 \mathrm{H}-\mathrm{CH}_{2}$ protons), 4.1 (s, $1 \mathrm{H}-\mathrm{NH}$ protons), 3.2 (s, $1 \mathrm{H}-\mathrm{CH}$ protons), 5.4 (s,1H-CH protons) and 7.0-7.8 (m, 22H-Ar-H), M.W-562.73 g/mol, EI-MS: m/z 562 (M-1).

5-(4-Dimethylamino-phenyl)-3-phenyl-4, 5-dihydro-pyrazole-1carbothioic acid [4-(9, 10-dihydro-acridin-9-yl)-phenyl]-amide (C4)

Cream color solid, yield-58\%, m.p. $307-310^{\circ} \mathrm{C}$, IR (KBr): $1604 \mathrm{~cm}^{-1}$ $(-\mathrm{NH}-), 1401 \mathrm{~cm}^{-1}(\mathrm{C}=\mathrm{S})$, and $1022 \mathrm{~cm}^{-1}\left(-\mathrm{N}\left(\mathrm{CH}_{3}\right)_{2},{ }^{1} \mathrm{H} \mathrm{NMR}\left(\mathrm{CDCl}_{3}\right)\right.$ : $\delta$ ppm: 1.1 (s, 2H-CH protons), 2.7 (s-6H-NCH $\left.\mathrm{N}_{3}\right), 4.0$ (s, $1 \mathrm{H}-\mathrm{NH}$ protons), 5.0 (s, $1 \mathrm{H}-\mathrm{CH}$ protons) and 6.9-8.0 (m, 22H, Ar-H), M.W-579.76 g/mol, EI-MS: m/z 579 (M-1).

5-(4-Nitro-phenyl)-3-phenyl-4, 5-dihydro-pyrazole-1-carbothioic acid [4(9, 10-dihydro-acridin-9-yl)-phenyl]-amide (C5)

Yellow color solid, yield-52\%, m.p. $314-317^{\circ} \mathrm{C}$, IR(KBr): $1595 \mathrm{~cm}^{-1}(-\mathrm{NH}-)$, $1450 \mathrm{~cm}^{-1}(\mathrm{C}=\mathrm{S})$, and $1575 \mathrm{~cm}^{-1}\left(-\mathrm{NO}_{2}\right),{ }^{1} \mathrm{H}$ NMR $\left(\mathrm{CDCl}_{3}\right): \delta \mathrm{ppm}: 1.3(\mathrm{~s}, 2 \mathrm{H}-$ $-\mathrm{CH}_{2}$ protons), 4.0 (s,1H-NH protons), 3.4 (s, $1 \mathrm{H}-\mathrm{CH}$ protons) and 6.8-7.8 (m, 21H-Ar-H), M.W-581.69 g/mol, EI-MS: m/z 581 (M-1), 583 (M+1).

5-(4-Hydroxy-phenyl)-3-phenyl-4, 5-dihydro-pyrazole-1-carbothioic acid [4-(9, 10-dihydro-acridin-9-yl)-phenyl]-amide (C6)

White color solid, yield-70\%, m.p. 327-330 ${ }^{\circ} \mathrm{C}$, IR (KBr): $1575 \mathrm{~cm}^{-1}$ (-NH-), $1469 \mathrm{~cm}^{-1}(\mathrm{C}=\mathrm{S})$, and $3520 \mathrm{~cm}^{-1}\left(-\mathrm{OH}\right.$, Phenolic), ${ }^{1} \mathrm{H}$ NMR $\left(\mathrm{CDCl}_{3}\right): \delta$ ppm: 2.1 (s, $2 \mathrm{H}-\mathrm{CH}_{2}$ protons), 3.9 (s, $1 \mathrm{H}-\mathrm{NH}$ protons), 3.2 (s,1H-CH proton), $5.0(\mathrm{~s}, 1 \mathrm{H}-\mathrm{OH}$, Phenolic protons) and 7.3-7.9 $(\mathrm{m}, 21 \mathrm{H}$, Ar-H) M.W-552.69 g/mol, EI-MS: m/z 553(M).

5-Methyl-3-phenyl-4, 5-dihydro-pyrazole-1-carbothioic acid [4-(9, 10-dihydro-acridin-9-yl)-phenyl]-amide (C7)

Cream color solid, yield-72\%, m.p. 295-297 C, IR (KBr): $1510 \mathrm{~cm}^{-1}$ (-NH-), $1444 \mathrm{~cm}^{-1}(\mathrm{C}=\mathrm{S})$, and $1461 \mathrm{~cm}^{-1}\left(-\mathrm{CH}_{3}\right),{ }^{1} \mathrm{H} \mathrm{NMR}\left(\mathrm{CDCl}_{3}\right): \delta \mathrm{ppm}$ : 2.1 (s, $2 \mathrm{H}, \mathrm{CH}_{2}$ protons), 4.8 (s,1H-NH protons), 3.2 (s, $1 \mathrm{H}-\mathrm{CH}$ proton), $1.4\left(\mathrm{~s}, 3 \mathrm{H}-\mathrm{CH}_{3}\right.$ protons) and 7.0-7.8 (m, 17H-Ar-H), M.W-474.62 g/mol, EI-MS: $\mathrm{m} / \mathrm{z}$ 475(M)

3-Phenyl-5-propenyl-4, 5-dihydro-pyrazole-1-carbothioic acid [4-(9, 10-dihydro-acridin-9-yl)-phenyl]-amide (C8)

White color solid, yield-59\%, m.p. $300-302^{\circ} \mathrm{C}$, IR (KBr): $1581 \mathrm{~cm}^{-1}$ $(-\mathrm{NH}-), 1508 \mathrm{~cm}^{-1}(\mathrm{C}=\mathrm{S}), 1469 \mathrm{~cm}^{-1}\left(-\mathrm{CH}_{3}\right)$, and $1342 \mathrm{~cm}^{-1}\left(-\mathrm{CH}=\mathrm{CH}_{2}\right)$, ${ }^{1} \mathrm{H}$ NMR $\left(\mathrm{CDCl}_{3}\right): \delta$ ppm: 2.0 (s, $2 \mathrm{H}-\mathrm{CH}_{2}$ protons), 4.0 (s,-NH protons), $3.2(\mathrm{~s}, 1 \mathrm{H}-\mathrm{CH}$ proton) 1.1 (s,3H-CH protons) 5.6 (s, $2 \mathrm{H}$ vinylic protons) and 7.3-7.8 (m, 17H-Ar-H), M.W-500.66 g/mol, EI-MS: m/z 500(M-1).

\section{In vitro cytotoxic activity}

In vitro cytotoxic studies of synthesized compounds of acridine tagged pyrazole derivatives compounds in comparison with reference drugs Doxorubicin (Dx) mitoxantrone (Mr) were studied by sulforhodamine-B (SRB) assay [20]. In brief, cells were cultured in RPMI 1640 supplemented with $10 \%$ fetal calf serum, and cultures were passaged once or twice a week using trypsin EDTA to detach the cells from their culture flasks. The fast-growing cells were harvested, counted, and plated at suitable concentrations in 96-well microplates. Cells were allowed to adhere for $24 \mathrm{~h}$. Thereafter, one plate was fixed to determine the initial absorbance $\left(\mathrm{T}_{0}\right)$. To the other plates compounds dissolved in the culture medium were added to the culture wells in triplicate and incubated further for 
$72 \mathrm{~h}$ at $37^{\circ} \mathrm{C}$ under $5 \% \mathrm{CO}_{2}$ atmosphere. The cultures were fixed with cold TCA and stained with $0.4 \%$ SRB dissolved in $1 \%$ acetic acid. After dissolving the bound stain with $150 \mathrm{uL}$ of $10 \mathrm{mM}$ unbuffered Tris-base (Tris(hydroxymethyl)aminomethane) solution using gyratory shaker, absorbance was measured at $540 \mathrm{~nm}$ using a microplate reader (Tecan). Growth was calculated by correcting the control plate (without drugs) cultured for $72 \mathrm{~h}$ ( $\mathrm{T}_{72}$ control) with the $\mathrm{T}_{0}$ plate. Growth inhibition was calculated as: $\left(\mathrm{T}_{72}\right.$ drug- $\left.\mathrm{T}_{0}\right) /\left(\mathrm{T}_{72}\right.$ control- $\left.\mathrm{T}_{0}\right) / 100 \%$. The efficacy of the compounds was compared by estimating the concentration required to inhibit cellular growth by $50 \%$ (i.e. $\mathrm{IC}_{50}$ ) from each separate growth inhibition curve. Each value represents the mean of triplicate experiments.

\section{Molecular docking and binding energy calculations}

Dataset ligands and ligand optimization cytotoxic activity possessing acridine tagged pyrazole derivatives which were earlier developed in our laboratory were selected (Scheme 1) [21]. 2D structures of the compounds were converted to 3D using potential algorithms and application of high efficient force fields. Initial geometrical optimization and energy minimization of molecules were performed using the LigPrep tool of Schrodinger suite [22]. Various ionization states were generated using LigPrep module using a special program EPIK along with various possible conformers and tautomers.

Molecular properties of the processed ligands were studied using Qikprop module. Qikprop module also predicts ADME profiles such as blockage of Human Ether-a-go-go-related Gene (hERG) K+ channels, apparent Caco-2 cell permeability, brain/blood partition coefficient, apparent Madin-Darby canine kidney cell permeability, skin permeability, binding to human serum albumin, and human oral absorption of the given set of ligands [23].

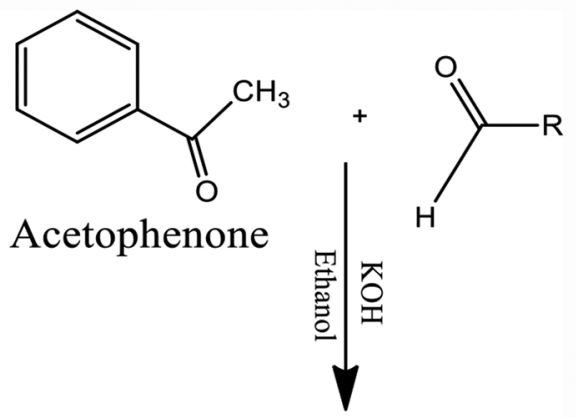

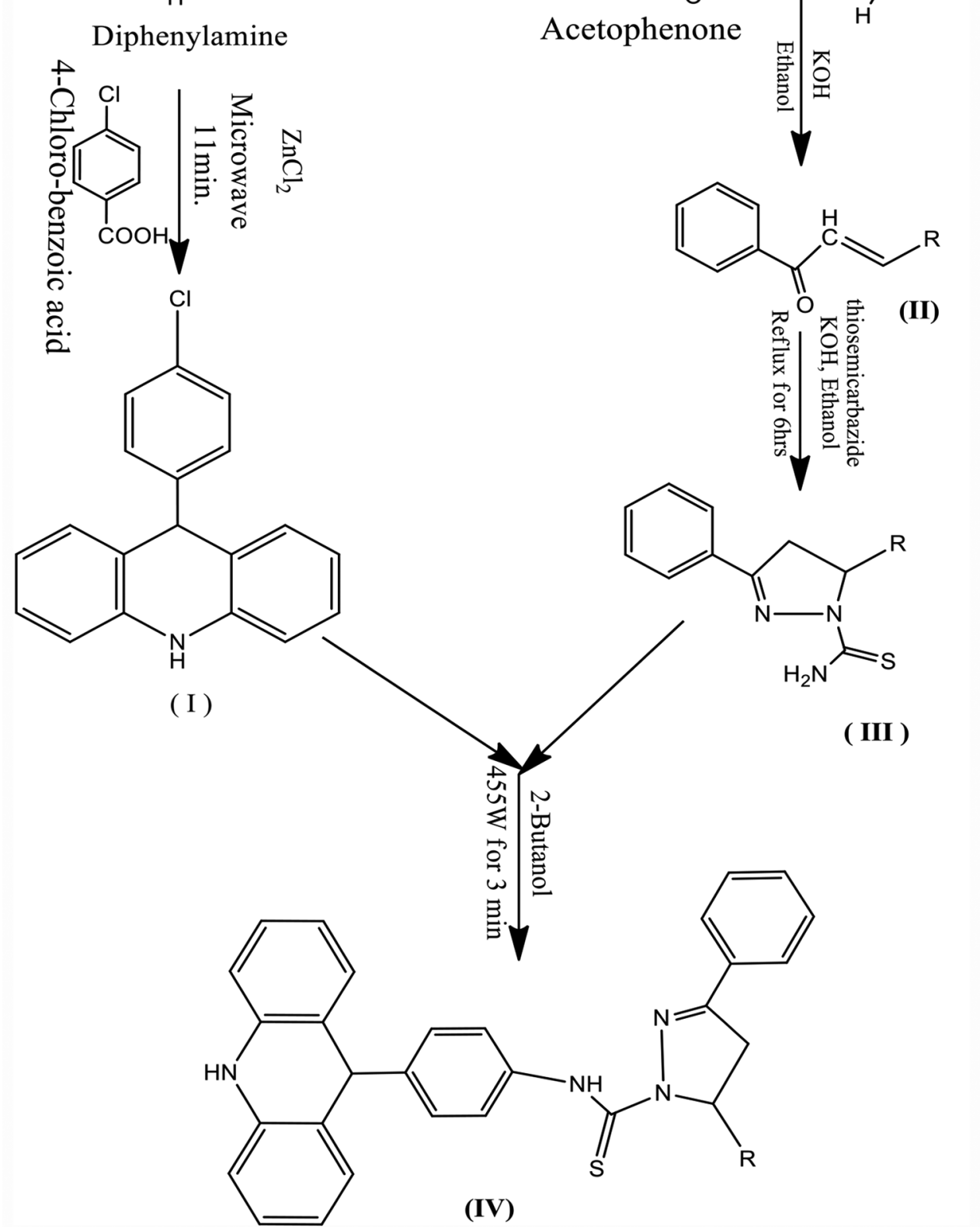

Scheme 1: Synthesis of acridine tagged pyrazole derivatives 
Table 1: Physical characterization data of acridine tagged pyrazole derivatives

\begin{tabular}{|c|c|c|c|c|c|}
\hline Molecule & $\mathbf{R}$ & MW & $\log P$ & Yield (\%) & $\operatorname{MP}\left({ }^{\circ} \mathrm{C}\right)$ \\
\hline C1 & & 552.69 & 8.18 & 70 & $310-312$ \\
\hline $\mathrm{C} 2$ & & 536.69 & 8.3 & 63 & $323-325$ \\
\hline $\mathrm{C} 3$ & & 562.73 & 8.82 & 55 & $310-312$ \\
\hline $\mathrm{C} 4$ & & 579.76 & 8.59 & 58 & $307-310$ \\
\hline C5 & & 589.61 & 7.99 & 52 & $314-317$ \\
\hline C6 & & 552.69 & 7.91 & 70 & $327-330$ \\
\hline $\mathrm{C} 7$ & & 474.62 & 6.91 & 72 & $295-297$ \\
\hline C8 & & 500.66 & 7.63 & 59 & $300-302$ \\
\hline C9 & & 571.13 & 8.86 & 69 & $280-283$ \\
\hline C10 & & 581.69 & 7.92 & 58 & $278-281$ \\
\hline C11 & & 526.65 & 6.92 & 72 & $261-263$ \\
\hline C12 & & 616 & 7.4 & 70 & $265-268$ \\
\hline C13 & & 616 & 7.92 & 69 & $263-265$ \\
\hline
\end{tabular}


Table 1: (Continued)

\begin{tabular}{|c|c|c|c|c|c|}
\hline Molecule & $\mathbf{R}$ & MW & $\log P$ & Yield (\%) & MP $\left({ }^{\circ} \mathrm{C}\right)$ \\
\hline C14 & & 581.69 & 7.65 & 63 & $252-255$ \\
\hline C15 & & 593.74 & 7.21 & 68 & 301-303 \\
\hline C16 & & 594.72 & 7.89 & 71 & $283-285$ \\
\hline C17 & & 582.71 & 7.79 & 68 & $275-278$ \\
\hline C18 & & 630.60 & 8.33 & 69 & $286-289$ \\
\hline C19 & & 566.71 & 8.18 & 71 & 291-293 \\
\hline $\mathrm{C} 20$ & & 645.61 & 9.01 & 65 & $310-312$ \\
\hline $\mathrm{C} 21$ & & 615.58 & 9.13 & 68 & 291-293 \\
\hline $\mathrm{C} 22$ & & 587.13 & 8.47 & 60 & $287-289$ \\
\hline $\mathrm{C} 23$ & & 642.81 & 9.91 & 64 & $278-281$ \\
\hline $\mathrm{C} 24$ & & 550.72 & 8.79 & 72 & $282-286$ \\
\hline $\mathrm{C} 25$ & & 616.13 & 8.89 & 66 & $271-274$ \\
\hline
\end{tabular}

(Contd...) 
Table 1: (Continued)

\begin{tabular}{|c|c|c|c|c|c|}
\hline Molecule & $\mathbf{R}$ & MW & $\log P$ & Yield (\%) & $\mathrm{MP}\left({ }^{\circ} \mathrm{C}\right)$ \\
\hline $\mathrm{C} 26$ & & 578.77 & 9.54 & 69 & $267-269$ \\
\hline $\mathrm{C} 27$ & & 605.58 & 9.42 & 68 & $301-303$ \\
\hline $\mathrm{C} 28$ & & 580.74 & 8.51 & 71 & $288-301$ \\
\hline $\mathrm{C} 29$ & & 564.74 & 9.28 & 66 & $283-285$ \\
\hline C30 & & 566.71 & 8.18 & 69 & $305-308$ \\
\hline
\end{tabular}

Table 2: Cytotoxic activity of acridine tagged pyrazole derivatives

\begin{tabular}{ll}
\hline Cell lines $/ \mathbf{I C}_{\mathbf{5 0}}(\boldsymbol{\mu M}) \pm$ SEM $^{\mathbf{a}}$ & \\
\hline Compound & MCF7/Wt \\
\hline IIIa & $23.2 \pm 0.7$ \\
IIIb & $25.2 \pm 0.5$ \\
C $_{1}$ & $10.2 \pm 0.2$ \\
C5 & $15.2 \pm 0.4$ \\
C6 & $08.2 \pm 0.4$ \\
C7 & $09.2 \pm 0.2$ \\
C11 & $10.2 \pm 0.3$ \\
C13 & $09.2 \pm 0.4$ \\
C14 & $12.2 \pm 0.5$ \\
C17 & $21.2 \pm 0.3$ \\
C20 & $17.2 \pm 0.4$ \\
C23 & $11.2 \pm 0.7$ \\
C27 & $18.2 \pm 0.8$ \\
Mitoxantrone (Mr) & 0.090 \\
Doxorubicin (Dx) & 0.098 \\
\hline
\end{tabular}

The digital structure of the Aurora-A kinase protein was retrieved from the protein databank website with PDB Id: 1MQ4 and the structure was optimized by deleting unbound water molecules which are over $1 \AA$ A , adding hydrogen atoms to satisfy the valences, adding missing amino acids to stabilize side chains and energy of the whole structure was minimized using OPLS-2005 force field using Protein Preparation Wizard tool of Schrodinger Suite [24]. Thus, structurally optimized protein structure was used to examine protein-ligand interactions of the dataset ligands using Glide Xp docking protocol. Initially, a 3D grid was established to the binding pocket (active site) of the protein, into which all the dataset ligands were docked into. Binding interactions and efficiency of the binding were calculated in terms of Glide Score, which is a combination of hydrophilic, hydrophobic, metal binding groups, Van der Waals energy, freezing rotatable bonds, and polar interactions with receptor [25]. GScore $=0.065 \times$ Van der Waals energy $+0.130 \times$ Coulomb energy+Lipophilic term (Hydrophobic interactions) $+\mathrm{H}$ bonding+Metal binding+BuryP (Penalty for buried polar groups)+RotB (Penalty for freezing rotatable bonds)+Site (Polar interactions in the active site) Post docking calculations Prime MM/GBSA (molecular mechanics based generalized Born/surface area), module of Schrodinger suite was used to calculate the binding energies of the docked complexes, which is a combination of OPLS molecular mechanics energies (EMM), an SGB solvation model for polar solvation (GSGB), and a non-polar solvation term (GNP) containing non-polar solvent accessible surface area and Van der Waals interactions. In this, docking results were rescored through an energy function with a well-defined description of binding contributions. The total free energy of binding is then expressed in the form below mentioned Equation [22]:

$$
\begin{gathered}
\Delta \text { Gbind }=\text { Gcomplex }-(\text { Gprotein }+ \text { Gligand }) \\
\text { Where, } \Delta \text { Gbind is ligand binding energy. }
\end{gathered}
$$

\section{RESULTS}

\section{Chemistry}

Acridine tagged pyrazole derivatives have been synthesized and the reaction sequence for the synthesis of compounds is outlined in Scheme 1. Physical Characterization data of newly synthesized compounds are outlined in Table 1. The protein ligand interactions and post docking calculations of acridine tagged pyrazole derivatives with aurora kinase are shown in Table 2. Cytotoxic activity of acridine tagged pyrazole derivatives is shown in Table 3.

\section{Cytotoxic activity}

All the synthesized compounds were evaluated for their cytotoxic activity against humanw breast cancer MCF/wt cell line by SRB assay using standard drug doxorubicin mitoxantrone.

For each cell line, the $\mathrm{IC}_{50}$ values (response parameter) were calculated and outlined in Table 2. 


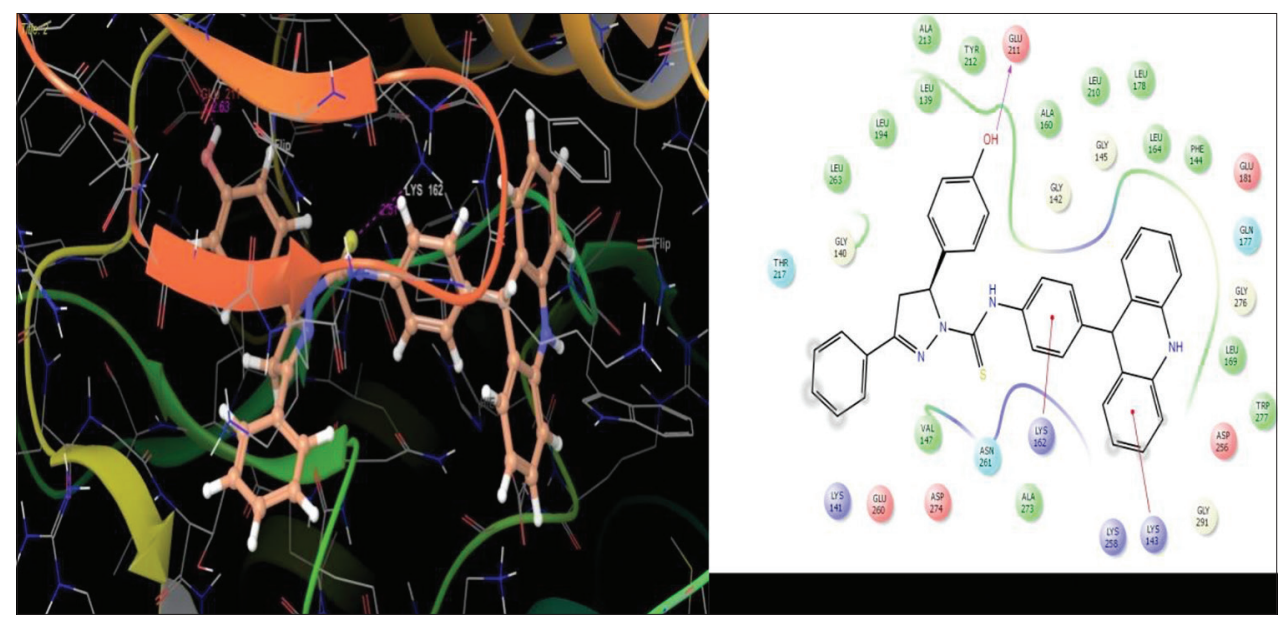

Fig. 1: Binding interactions of compound C6 at kinase domain of aurora kinase protein

Table 3: Protein ligand interactions and post docking calculations of acridine tagged pyrazole derivatives with aurora kinase

\begin{tabular}{|c|c|c|c|c|c|}
\hline Compound & Dock score & No of H-bonds & Interacting amino acids & H-bond distance & Bond energy \\
\hline \multirow[t]{3}{*}{ C6 } & -8.926 & 3 & GLU 211 & 2.63 & -86.32133 \\
\hline & & & LYS 162 & 2.51 & \\
\hline & & & LYS 143 & 2.29 & \\
\hline \multirow[t]{3}{*}{ c5 } & -8.773 & 3 & ASN 261 & 2.29 & -73.793 \\
\hline & & & ASP 256 & 2.01 & \\
\hline & & & LYS 258 & 2.17 & \\
\hline \multirow[t]{2}{*}{ c20 } & -6.972 & 2 & LEU 139 & 2.61 & -68.989 \\
\hline & & & TRP 277 & 2.03 & \\
\hline c19 & -6.617 & 1 & LEU 139 & 2.66 & -69.017 \\
\hline c18 & -6.545 & 1 & LEU 139 & 2.66 & -69.696 \\
\hline c27 & -6.418 & 1 & LYS 258 & 2.74 & -72.608 \\
\hline c16 & -6.405 & 1 & LEU 139 & 2.75 & -74.62 \\
\hline c30 & -6.36 & 0 & - & - & -73.519 \\
\hline c23 & -6.357 & 1 & LEU 139 & 2.70 & -77.467 \\
\hline c25 & -6.344 & 1 & LEU 139 & 2.32 & -68.847 \\
\hline c17 & -6.281 & 1 & LEU 139 & 2.66 & -72.458 \\
\hline c4 & -6.266 & 1 & LEU 139 & 2.67 & -70.836 \\
\hline \multirow[t]{2}{*}{ c21 } & -6.225 & 2 & LEU 139 & 2.60 & -68.579 \\
\hline & & & LYS 258 & 2.78 & \\
\hline c28 & -6.216 & 0 & - & - & -71.688 \\
\hline c26 & -6.171 & 0 & - & - & -65.321 \\
\hline c3 & -6.154 & 0 & - & - & -73.544 \\
\hline c22 & -6.117 & 1 & LEU 139 & 2.79 & -67.504 \\
\hline c29 & -6.112 & 0 & - & - & -72.295 \\
\hline c13 & -6.091 & 1 & LEU 139 & 2.51 & -64.779 \\
\hline c14 & -6.077 & 0 & - & - & -71.29 \\
\hline \multirow[t]{2}{*}{ c12 } & -6.011 & 2 & LEU 139 & 2.56 & -63.903 \\
\hline & & & LYS 258 & 2.78 & \\
\hline c1 & -6.001 & 0 & - & - & -64.898 \\
\hline c10 & -5.996 & 1 & TRP 277 & 1.91 & -62.737 \\
\hline \multirow[t]{2}{*}{ c2 } & -5.924 & 2 & LEU 139 & 2.64 & -65.869 \\
\hline & & & LYS 258 & 2.79 & \\
\hline c15 & -5.741 & 2 & LYS 258 & 2.33 & -71.744 \\
\hline c11 & -5.669 & 1 & LEU 139 & 2.50 & -70.09 \\
\hline c8 & -5.468 & 0 & - & - & -61.574 \\
\hline c24 & -5.139 & 1 & LYS 258 & 2.25 & -65.201 \\
\hline
\end{tabular}

\section{Molecular docking and binding energy calculations}

The association of Aurora kinase in the human breast cancers was observed from the previous reports. The dock scores of the tested compounds were ranged between -8.926 and -5.139 . Compound C6 has been reported as the most effective cytotoxic agent among the series also reported the highest dock score of -8.926 and showed hydrogen bond interaction with GLU-211, LYS-162, and LYS-143 (Fig. 1). Ligand binding energy with protein suggested that compound C6 has shown the highest binding energy of $-86.32133 \mathrm{kcal} / \mathrm{mol}$, protein-ligand interactions along with binding energies of acridine tagged pyrazole derivatives with aurora kinase are shown in Table 3.

The majority of interactions are observed with acridone $\mathrm{N}$-atom with LEU 139. Substituted halogens also show substantial interactions. 


\section{DISCUSSION}

We have designed a convenient method for the synthesis of acridine tagged pyrazole derivatives and screened for in vitro cytotoxic activity against human breast cancer cell lines MCF/wt. By observing the above results, these synthesized compounds showed good cytotoxic activity of $\mathrm{IC}_{50}$ values in the range of $08.2 \pm 0.4-21.2 \pm 0.3$. The electron releasing $\mathrm{OH}$ group in compound $\mathrm{C} 6$ is responsible for good binding interaction at kinase domain of aurora kinase protein.

\section{CONCLUSION}

In the present study, novel acridine tagged pyrazole derivatives were synthesized. The synthesized compounds were characterized by IR, ${ }^{1} \mathrm{H}$ NMR, ${ }^{13} \mathrm{C}$ NMR, and mass spectrum. All the synthesized compounds showed characteristic absorption peaks in $\mathrm{IR},{ }^{1} \mathrm{H}$ NMR, and mass spectrum. Synthesized compounds were evaluated for in vitro cytotoxic activity by SRB assay against human breast cancer cell lines MCF/wt.

The cytotoxic activity of the synthesized compounds revealed that the maximum activity was obtained when $\mathrm{R}$ was substituted by a hydroxyl group in the phenyl ring of pyrazole moiety. It was found that the compounds possessing electron releasing groups considerably enhance the cytotoxic activity when compared to the electron withdrawing groups on the phenyl ring.

\section{ACKNOWLEDGMENTS}

We thank the principals and management of Teegala Krishna Reddy College of Pharmacy, Hyderabad, Vishnu Institute of Pharmaceutical Education and Research, Narsapur, for providing facilities to carry out the work.

\section{AUTHOR'S CONTRIBUTIONS}

HarathiPerka and Vivekananda Boya contributed to the experimental work and preparation of the manuscript, Deepak Reddy Gade and Dr. Satyavati supervised the manuscript preparation and Dr. V.V.S. Rajendra Prasad organized and reviewed the manuscript.

\section{CONFLICTS OF INTEREST}

The authors declare that they have no conflicts.

\section{REFERENCES}

1. Siegel RL, Miller KD, Jemal A. Cancer statistics. CA Cancer J Clin 2017;67:7-30.

2. Katayama H, Subrata S. Aurora kinase inhibitors as anticancer molecules. Biochim Biophys Acta 1799;2010:829-39.

3. Albert A. The Acridines. New York: St. Martin's Press; 1966. p. 403504.

4. Greenwood D. Conflicts of Interest: The genesis of synthetic antimalarial agents in peace and war. J Antimicrob Chemother 1995;36:857-72.

5. Grove WR. Review of amsacrine, an investigational antineoplastic agent. Clin Pharm 1982;1:320-6.

6. Van Mouwerik TJ, Caines PM, Ballentine R. Amsacrine evaluation. Drug Intell Clin Pharm 1987;21:330-4.
7. Jehn U. Stem cell transplantation in chronic lymphocytic leukemia. Biol Blood Bone Marrow Transplant 1989;3:53-8.

8. Harousseau JL. New therapies for acute myeloid leukaemia. Blood 1997:90:2978-86.

9. Prasad VV, Reddy GD, Kathmann I, Amareswararao M, Peters GJ. Nitric oxide releasing acridonecarboxamide derivatives as reverters of doxorubicin resistance in MCF7/Dx cancer cells. Bioorg Chem 2016;64:51-8.

10. Jelic S, Nikolic-tomasevic Z, Kovcin V, Milanovic N, Tomasevic Z, Jovanovic $\mathrm{V}$, et al. A two-step reevaluation of high-dose amsacrine for advanced carcinoma of the upper aerodigestive tract: A pilot phase II study. J Chemother 1997;9:364-70.

11. Urmila G, Sareen V, Khatri V, Chugh S. Synthesis and antifungal activity of new fluorine containing 4-(substituted phenylazo) pyrazoles and isoxazoles. Indian J Heterocycl Chem 2005;14:265-6.

12. Eicher T, Hauptmann S. Chemistry of Heterocycles: Structure, Reactions, Syntheses, and Applications. Weinheim, Germany: WileyVCH; 2003.

13. Talley JJ, Donald, Rogier J. Priviledged synthesis of pyrazole [1, 3, 4] thiadiazol-[1, 3, 4] oxadiazole-2-thione derivatives. Glob J Res Anal $1995 ; 4: 15-6$

14. Pimerova EV, Voronina EV. Antimicrobial activity of pyrazoles and pyridazines obtained by intreraction of 4-aryl-3- arylhydrazono-2, 4-dioxobutanoic acids and their esters with hydrazines. Pharm Chem J 2001;35:602-4.

15. Yildirim I, Ozdemir N, Akcamur Y, Dincer M, Andac O. 4-Benzoyl-1, 5-Diphenyl-1H-Pyrazole-3-Carboxylic Acid Methanol Solvate. Hoboken: Wiley; 2005

16. Bailey DM, Hansen PE, Hlavac AG, Baizman ER, Pearl J, DeFelice AF, et al. 3,4-Diphenyl-1H-pyrazole-1-propanamine antidepressants. J Med Chem 1985;28:256-60.

17. Amr AE, Abdel-Latif NA, Abdlla MM. Synthesis of some new testosterone derivatives fused with substituted pyrazoline ring as promising 5alpha-reductase inhibitors. Acta Pharm 2006;56:203-18.

18. Chimichi S, Boccalini M, Hassan MM, Viola G. Dall'Acqua F, Curini M. Synthesis, structural determination and photo-antiproliferative activity of new 3-pyrazolyl or-isoxazolyl substituted 4-hydroxy-2(1H)quinolinones. Tetrahedron 2006;62:90-6

19. Li X, Lu X, Xing M, Yang XH, Zhao TT, Gong HB, et al. Synthesis, biological evaluation, and molecular docking studies of $\mathrm{N}, 1,3-$ triphenyl-1H-pyrazole-4-carboxamide derivatives as anticancer agents. Bioorg Med Chem Lett 2012;22:3589-93

20. Keepers YP, Pizao PE, Peters GJ, van Ark-Otte J, Winograd B, Pinedo HM. Comparison of the sulforhodamine B protein and tetrazolium (MTT) assays for in vitro chemosensitivity testing. Eur J Cancer 1991;27:897-900.

21. Harathi P, Prasad VS, Satyavati S, Subramanian S, Boya V, Gali P. Asian J Pharm Clin Res 2015;8:83-7.

22. LigPrep. Version 2.7. USA: Schrodinger LLC; 2016.

23. Gade DR, Kunala P, Raavi D, Reddy PV, Prasad RV. Structural insights of JAK2 inhibitors: Pharmacophore modeling and ligandbased 3D-QSAR studies of pyrido-indole derivatives. J Recept Signal Transduct Res 2015;35:189-201.

24. Reddy GD, Kumar KN, Duganath N, Divya R, Amitha K. ADMET, Docking studies and binding energy calculations of some novel ACEinhibitors for the treatment of diabetic nephropathy. Int J Drug Dev Res 2012;4:268-82.

25. Chaitanya P, Reddy GD, Varun G, Srikanth LM, Prasad VV, Ravindernath A. Design and synthesis of quinazolinone derivatives as anti-inflammatory agents: Pharmacophore modeling and 3D QSAR studies. Med Chem 2014;10:711-23. 